rehulyrovanyy nauchno-tekhnycheskoho prohressa [New in the legal regulation of scientific and technological progress]. Problemy pravovedenyia. Respublykanskyi mezhduvedomstvennyi nauchnyi sbornyk [Problems of jurisprudence. Republican interdepartmental scientific collection]. Vyp. 46. Kyev: Vyshcha shk. (in Russian).

16. Azymov Ch.N. (1976) Vlyianye nauchno-tekhnycheskoho prohressa na yurydycheskuiu pryrodu dohovorov [The impact of scientific and technological progress on the legal nature of contracts]. Problemy sotsyalystycheskoi zakonnosty [Problems of socialist legality]. Vyp. 1. Kh., Vyshcha shk. (in Russian)

17. Azymov Ch.N. (1981) Dohovornye otnoshenyia v oblasty nauchno-tekhnycheskoho prohressa [Contractual relations in the field of scientific and technological progress]. Kharkov. Khark. yuryd in (in Russian).

18. Musyiaka V.L. (1988) Avtorskye dohovory [Copyright agreements]. Kyev (in Russian).
19. Pidopryhory O.A.,Sviatotskohyi O.D. (2002). Pravo intelektualnoi vlasnosti [Intellctual Property Law]. Pidruchnyk dlia studentiv vyshchykh navch. zakladiv. K., In Yure. (in Ukrainian)

20. Pidopryhora O. A., Pidopryhora O. O. (1998) Pravo intelektualnoi vlasnosti Ukrainy [Intellctual Property Law of Ukraine]. Navchalnyi posibnyk dlia studentiv yurydychnykh vuziv i fakultetiv universytetiv. Kyiv, Yurinkom Inter. (in Ukrainian).

21. Kyivska shkola tsyvilistyky [Kiev School of Civil Law]. (2009) / Do 175-richchia Kyivskoho natsionalnoho universytetu imeni Tarasa Shevchenka. 1834-2009 / Za red. R.A. Maidanyka. K., Alerta; KNT; TsUL, (in Ukrainian).

Received: $28 / 07 / 2021$ Accepted: $18 / 08 / 2021$

A. Kodynets, Dr. Sc. (Law), Associate Prof.

Taras Shevchenko National University of Kyiv, Kyiv, Ukraine

\title{
SCIENCE OF INTELLECTUAL PROPERTY LAW: CONCEPTS, FEATURES AND DIRECTIONS FOR THE DEVELOPMENT
}

The article explores the concepts, features and directions for the development of intellectual property science at the present stage. The basic scientific schools of intellectual property law are analysed, the specifics of their formation and genesis are considered.

The article emphasizes that the science of intellectual property law is a system of knowledge and theoretical ideas about the laws of legal regulation of relations in the field of protection of intellectual and creative activities, interpretation of legal norms and the results of analysis and generalization of their application.

As intellectual property right, the science of intellectual property law is a relatively young field in the legal system; however, it already has a long history of development, well-known representatives and scientific schools, including those pertaining to Taras Shevchenko National University of Kyiv.

The development of intellectual property science in Ukraine is based on several scientific schools in Kyiv, Odessa, Lviv and Kharkiv, which are represented by powerful research centres and educational institutions.

The Kyiv School of Intellectual Property is formed by two research centres: the Department of Intellectual Property and Information Law of Taras Shevchenko National University of Kyiv and the Research Institute of Intellectual Property of the National Academy of Sciences of Ukraine.

The origin and development of the science of intellectual property law in Taras Shevchenko National University of Kyiv is associated with the figure of the famous domestic scientist O.A. Hills. Since 2013, the Department of Intellectual Property and Information Law has been operating at the Faculty of Law of Taras Shevchenko National University of Kyiv. At the current stage, the Department of Intellectual Property and Information Law jointly with the Scientific and Educational Centre for Intellectual Property of Taras Shevchenko National University of Kyiv make a powerful centre of the development of intellectual property law science in Ukraine.

Keywords: intellectual property, science, methodology, legal category, scientific school, scientist.

Bulletin of Taras Shevchenko National University of Kyiv. Legal Studies, 2021; 3 (118): 51-56 удК: 349.6

DOI: https:doi.org/10.17721/1728-2195/2021/3.118-9
ISSN 1728-2195

(C) Taras Shevchenko National University of Kyiv, Publishing center "Kyiv University", 2021

М. В. Краснова, д-р юрид. наук, проф. Київський національний університет імені Тараса Шевченка, Київ, Україна ORCID ID: 0000-0002-7453-8802

\section{ОСНОВИ ФОРМУВАННЯ СУЧАСНОЇ ЕКОЛОГІЧНОЇ ДЕРЖАВИ В УКРАЇНІ}

Досліджено соціальні, економічні, екологічні та правові засади формування сучасної екологічної держави та перспективи побудови такої держави в Україні на засадах реалізації державної політики. Розглянуто особливості реалізації окремих принципів державної політики, здатних сприяти у формуванні екологічної держави. На підставі аналізу формування таких держав у деяких країнах світу запропоновано шляхи удосконалення правових засад формування екологічно спрямованого суспільства, екологічного партнерства як основного способу побудови екологічної держави та забезпечення паритету екологічних, економічних і соціальних потреб у контексті сталого розвитку. Особливу увагу приділено формуванню екологічної парадигми як основи екологічної правосвідомості всього суспільства, що дозволить здійснити перегляд ціннісних орієнтирів у взаєминах із природою та визнати природу на рівні Конституції України основною соціальною цінністю, як це здійснено на конституційних засадах в окремих краӥнах. Також приділено увагу структурі, формам, методам, способам та змісту екологічного партнерства, здатного вплинути на різні чинники формування екологічної держави. Доведено, що основною формою екологічного партнерства в сучасних умовах є державно-приватне партнерство, яке здатне забезпечувати реалізацію ефективних екологічних проєктів у галузях відновлення природних ресурсів, поводження з відходами, екологічного туризму тощо. Екологічне партнерство за структурою запропоновано розелядати як сукупність інституційної, регулятивної, функціональної та комунікативної підсистем, а також розкрито можливий їхній зміст. На підставі проведеного дослідження запропоновано самостійні наукові висновки та судження з аналізованої тематики, зокрема і пропозиції про шляхи вдосконалення чинного законодавства України з окреслених питань.

Ключові слова: екологічна демократія; екологічна парадигма; екологічна правосвідомість; екологічна політика; принцип екологічного партнерства; екологічне законодавство.

\section{ВСТУП}

За даними звіту, який щорічно готує мережа ООН зі сталого розвитку з опитування громадян у кожній країнічлені ООН за критеріями, що включають соціальну державну підтримку, особисті та громадянські свободи, тривалість життя, дохід на душу населення та рівень корупції, уже четвертий рік поспіль Фінляндія визнається найщасливішою країною у світі. Це країна з високим рівнем доходу, бездоганно організованою освіт- ньою системою, з високою культурою самообслуговування та, що дуже важливо, з надзвичайно високими постійними позитивними зв'язками населення з владою та навколишнім природним середовищем [1].

На рівень формування щасливих країн певною мірою впливає багато чинників. Наприклад, лише показники співвідношення державних витрат на охорону навколишнього природного середовища до ВВП у країнах-членах $€ C$ складають близько 2 \% - від 0,2 \% у 
Фінляндії, 0,3 \% на Кіпрі та Литві, 0,4 \% у Данії, Ірландії, Угорщині та Австрії до понад $1 \%$, на Мальті, у Бельгії та Греції (по 1,3 \%) та в Нідерландах (1,4 \%) [2]. Водночас в Україні у середньому зведений бюджет на навколишнє середовище становить лише близько 0,4 \% ВВП [3]

Метою цієї статті є спроба дати відповідь: чи є перспективи в України бути щасливою, зокрема екологічною країною? Спробуємо проаналізувати таке на існуючих засадах формування в Україні соціальної, правової, екологічно спрямованої демократичної держави. Зазначимо, що в юридичній науці питання формування демократичної, соціальної, правової держави постійно порушують представники різних правових наук [4]. В екологічному праві такі питання розкриваються передусім шляхом аналізу ефективності державної екологічної політики [5], шляхом дослідження механізмів реалізації та захисту екологічних прав громадян як основи формування сучасного українського громадянського суспільства [6] тощо.

\section{ВИКЛАД ОСНОВНОГО МАТЕРІАЛУ}

Реаліям сьогодення притаманні глибокі докорінні зміни у всіх сферах життєдіяльності суспільства, особливо у процесі формування сучасної, екологічно спрямованої, соціально-правової, демократичної держави. Такі зміни потребують гармонізації екологічних і пов'язаних із ними інтересів різних соціальних груп, бізнесу, науки, суспільства в цілому і владних державних структур шляхом упровадження сучасних організаційних, економічних, правових та інших засобів. Це можливо здійснити впровадженням і регулюванням суспільних екологічних відносин з формування екологічно вмотивованого суспільства, підвищенням рівня екологічної правосвідомості населення, а також відносин партнерського типу. Правові засади доцільності регулювання таких відносин закладено Конституцією України, Законами України "Про охорону навколишнього природного середовища", "Про державно-приватне партнерство", багатьма іншими та передусім Основними засадами (стратегією) державної екологічної політики України на період до 2020 року, затвердженими Законом України від 28 лютого 2019 року № 2697-VIII [7].

Принагідно зазначимо, що демократичні засади побудови в Україні демократичної, правової, соціальноекологічної держави започатковано 30 років тому з прийняттям Закону України "Про охорону навколишнього природного середовища" (1991), в якому вперше закріплено систему екологічних прав громадян і гарантій їхньої реалізації і захисту (Розділ 2). Особливо важливими є визначені Законом правові форми участі громадян при прийнятті екологічно важливих рішень, зокрема: а) в обговоренні проєктів нормативно-правових актів, проєктів будівництва, експлуатації, реконструкції, здатних впливати на стан довкілля; б) в оцінюванні впливу планованої діяльності на стан довкілля; в) у стратегічній екологічній оцінці загальнодержавних планів, програм, які можуть мати вплив на навколишнє природне середовище; г) у загальнодержавних і місцевих референдумах 3 екологічних питань; д) у здійсненні природоохоронних заходів 3 відновлення стану навколишнього природного середовища;є) в екологічному інформуванні; ж) у здійсненні громадського екологічного контролю та моніторингу; и) у формуванні екологічних партій та організацій; к) у висловленні своєї думки, зокрема шляхом проведення екологічних мітингів і демонстрацій; л) в екологічній освіті й вихованні; м) у доступі до правосуддя з питань довкілля тощо.

Конституція України (1996) лише згодом визнала екологічні права людини і громадянина (ст. 50), установила обов'язок держави забезпечувати екологічну безпеку (ст. 16) та заклала інші положення існування в кра- їні потужної екологічної демократії. На розвиток таких положень в останні роки прийнято чимало Законів України, які розширюють інститути екологічної демократії: "Про звернення громадян", "Про доступ до публічної інформації", "Про громадські об'єднання", "Про оцінку впливу на довкілля", "Про Стратегічну екологічну оцінку", "Про народовладдя через всеукраїнський референдум" та багато інших.

Спрямованість держави щодо посилення залучення своїх громадян до спільного розв'язання екологічних проблем визначено в Законі України "Про Основні засади (стратегію) державної екологічної політики України на період до 2030 року" (2020), в Указах Президента України 24 березня 2021 року "Про Національну стратегію у ссрері прав людини", "Про рішення Ради національної безпеки і оборони України від 23 березня 2021 року "Про виклики і загрози національній безпеці України в екологічній сфері та першочергові заходи щодо їх нейтралізації", в інших документах.

Тому формування та реалізація державної політики у відповідній сфрері нині грунтується на принципі: жодні рішення для громадянського суспільства не можуть прийматися без громадянського суспільства. Це означає постійну співпрацю органів державної влади, органів місцевого самоврядування й інших інститутів громадянського суспільства на всіх етапах сталого природокористування, охорони довкілля та забезпечення екологічної безпеки.

У літературі традиційно пов'язують розв'язання багатьох екологічних проблем із рівнем еколого-правової освіти, культури, свідомості суспільства. Підвищення рівня екологічної освіти та виховання, екологічної культури та науки визначено основною ціллю державної екологічної політики у Законі України від 21 грудня 2010 року "Про основні засади (стратегію) державної екологічної політики на період до 2020 року".

Отож для формування екологічної держави передусім доцільно підвищувати рівень екологічної правосвідомості, яка $€$ похідною від загального поняття "правосвідомості", тобто форми суспільної свідомості, що містить сукупність поглядів, почуттів, емоцій, ідей, теорій і концепцій, а також уявлень і настанов, які характеризують відношення особи, суспільної групи і суспільства в цілому до чинного чи бажаного права, а також до всього, що охоплюється правовим регулюванням [8].

Поняття терміну "правосвідомість" співвідноситься певною мірою з поняттям "парадигма" - з багатозначним поняттям, яке залежне від контексту та може означати певний, обумовлений часом та обставинами сталий на певний період стиль, традицію, концепцію, генеральну ідею, закон тощо, за зміною яких можна застосувати граничні умови - зміни парадигми [9, с. 465]. Тому у межах формування еколого-правової свідомості слід вести мову про еколого-правову парадигму, яку доцільно розглядати як сукупність фрілософрсько-правових, загальнотеоретичних основ правових наук, тобто як систему понять і уявлень, термінів і категорій, які властиві кожному періоду розвитку держави та права.

У сучасних умовах правовим наукам, на засадах такого принципу державної екологічної політики як міжсекторальне партнерство у справі охорони довкілля, доцільно брати до уваги підходи до поняття "екологічна парадигма", що вживається загальною екологією як системна парадигма, згідно з якою екологічна система $\epsilon$ головним об'єктом сучасної екології та яка включає в себе всі живі й неживі компоненти природи [9]. У такому значенні саме екологічні системи, або ж Природа, мають розглядатися як основні об'єкти правового регулювання використання, відтворення й охорони. 
На таких засадах сучасні екологічно вмотивовані представники суспільства пропонують формувати в Україні екологічну демократію, тобто такий політичний устрій держави, за якого враховуються права не тільки людей, а й тварин, рослин, мікроорганізмів, екосистем, або ж Природи [10]. В екологічній демократії визнається основна соціальна цінність - Природа та їі права.

Як свідчать дані інтернет-джерел, права́ приро́ди це потреби, домагання, інтереси природи, розглядувані як моральний партнер, який захищається морально і законом [11].

Права природи відтак можна розглядати в об'єктивному і суб'єктивному значенні: по-перше, в об'єктивному значенні, - це система правил поведінки, система регулювання суспільних відносин із природою; подруге, в суб'єктивному значенні, - це визнані домагання будь-якої живої істоти, екосистеми на відповідне благо, якийсь інтерес у чому-небудь.

Права природи не існують самі по собі, а $є$ відбиттям моралі й етики конкретного людського суспільства або його груп. Вони є своєрідним засобом контролю за владою людини, яка не повинна переступати межу свободи, окресленої правами природи. Право - це регулятор суспільних відносин. У такому випадку права природи регулюють наші стосунки з природою. Природа має права тією мірою, в якій ми приймаємо обмеження своєї власної поведінки заради її інтересів [11].

Побудова екологічної демократії потребуватиме додаткової системи стримувань і противаг, яка буде захищати об'єкти Природи від свавілля з боку людей і водночас не буде суперечити загальним принципам демократії. Для дієвого захисту прав природи при екологічній демократії мають бути створені спеціальні суди з прав природи. Інтереси природних об'єктів у них можуть представляти спеціальні адвокати, а на правах опікунів постраждалих тварин і рослин будуть представники природоохоронних громадських організацій або ж уповноважений із прав тварин (природи). Права природи - це нова потужна культурна ідея XXI століття. Це навіть більше ніж ідея - це цілий новий суспільнополітичний та екологічний рух [11].

3 метою посилення засад формування екологічної демократії пропонується в Конституції України до основних соціальних цінностей віднести Природу та її права. До прикладу, Конституція Еквадору є першою у світі, де юридично закріплені права природи, окремих екологічних систем, таких як басейни річок [12].

Цікавою у такому контексті є Конституція Швейцарії, яка "прийнята в ім'я Всемогутнього Бога" (що є природною основою існування всього на Землі). За цією Конституцією народ і швейцарські кантони, усвідомлюючи свою відповідальність перед Творцем, повні рішучості оновити свій союз із метою зміцнення свободи, демократії, незалежності і миру в дусі солідарності та відкритості до світу, спонуканні жити в єдності притаманних відмінностей, дотримуючися поваги один одного і справедливості, усвідомлюючи наявність спільних досягнень $і$ свою відповідальність перед майбутніми поколіннями та інше, Конфедерація бере на себе зобов'язання щодо тривалого збереження природних ресурсів і справедливого й мирного міжнародного правопорядку (преамбула цієї Конституції) [13].

Формування екологічно спрямованої, демократичної, правової, а отже щасливої країни Україна має здійснювати шляхом реалізації державної екологічної політики, метою якої є досягнення доброго стану довкілля за рахунок запровадження екосистемного підходу до всіх напрямів соціально-економічного розвитку України з метою забезпечення конституційного права кожно- го громадянина України на чисте та безпечне довкілля, упровадження збалансованого природокористування і збереження та відновлення природних екосистем (розділ II Основних засад (стратегії) державної екологічної політики України на період до 2030 року).

Міжсекторальне партнерство та залучення зацікавлених сторін (далі - екологічне міжсекторальне партнерство) розглядається цією Стратегією у таких значеннях: а) як основна засада (принцип) екологічної політики, i, що особливо важливо, б) як важливий інструмент реалізації національної екологічної політики, який дасть змогу залучити до планування і реалізації політики всіх зацікавлених сторін - органи державної влади й органи місцевого самоврядування, суб'єктів господарювання, приватний сектор, науковців, громадськість.

Реалізація такого інструменту державної екологічної політики має відповідати принципам гласності та відкритості під час прийняття екологічно важливих рішень, участі громадськості у фрормуванні державної екологічної політики, заохочення до ведення екологічно відповідального бізнесу й екологічно свідомої поведінки громадян тощо.

Як видно, таке партнерство виступає одним із видів соціального партнерства. Науково-теоретичні аспекти з'ясування суті, значимості, структури, змісту, фрорм такого партнерства можна запозичити з положень загальної соціології [14], політології [15], теорії управління [16], які предметно досліджують питання цього сучасного соціального явища.

Так, у зарубіжній літературі "міжсекторальне соціальне партнерство найчастіше тлумачиться як співпраця між урядовими організаціями, корпораціями бізнесу і некомерційними організаціями з метою забезпечення сталого розвитку відповідного регіону". Наприклад, М. Уорнер і П. Грінер визначають таке партнерство як союз між сторонами, що представляють уряд, бізнес, громадянське суспільство, в якому стратегічно об'єднуються ресурси і здібності кожної зі сторін і яке засноване на принципах розподілу ризиків, витрат і загальної вигоди [17].

За іншим визначенням "міжсекторальне соціальне партнерство - це конструктивна взаємодія організацій із двох або трьох секторів (держава, бізнес, некомерційний сектор) у ході розв'язання соціальних проблем, що забезпечує синергетичний ефект від "складання" різних ресурсів і "корисний" кожній зі сторін і населенню" [18].

3 урахуванням різних тлумачень соціального партнерства, екологічне міжсекторальне партнерство можна розглядати системно як: а) механізм узгодження екологічних інтересів різних суспільних груп; б) систему колективних дій, що здійснюються для досягнення спільних екологічно виважених цілей; в) сукупність органів, організацій, що створюються з представників різних секторів для врегулювання екологічних відносин; г) процесуально-соціальну взаємодію між різними групами з різними соціально-економічними інтересами для врегулювання екологічних конфрліктів; д) організаційне зменшення екологічних ризиків, запобігання екологічної небезпеки і розв'язання екологічних проблем; е) у духовно-ціннісному вимірі - як ідеологію цивілізованого співжиття громадян в умовах ринкової економіки, новим типом мислення, центром якого $є$ людина і загальнолюдські цінності, такі як Природа.

Найбільша роль у реалізації екологічного міжсекторального партнерства відводиться державі та ії інституціям. Оскільки за змістом екологічне міжсекторальне партнерство - це реалізація нового рівня екологічного управління, що використовується у сфері надання еколого-соціальних послуг, у створенні сучасної екологічної інфрраструктури тощо. Це дасть можливість поєднати механізми державного і самоврядного управління з самоуправлінням громадян, з системами екологічного 
управління на виробництві (з екологічним менеджментом), сфрормувати новий тип взаємовідносин між ними.

Такі підходи відповідають цілі 5 Стратегії державної екологічної політики, а саме: удосконалення та розвиток державної системи природоохоронного управління, завданням якого $є$ впровадження принципів належного екологічного врядування, підтримка постійного діалогу із зацікавленими сторонами щодо підготовки та прийняття стратегічних рішень тощо.

Як механізм екологічного управління міжсекторальне партнерство є системою способів, засобів, прийомів, завдяки яким здійснюються відповідні законодавчо визначені завдання і функції управління. У межах структури механізму екологічного управління таке партнерство за рівнями управління і регулювання формується на: мікрорівні (об'єктовий, особовий); мезорівні (груповий, колективний); макрорівні (суспільний, загальнодержавний); мегарівні (рівень нації, етносу, міжнародний) [19].

3 огляду на визначення інших підходів до структури системи соціального партнерства, систему екологічного міжсекторального партнерства можна розглядати як інституційну, регулятивну, функціональну та комунікативну підсистеми [20].

Так, до інституиійної підсистеми можуть входити постійно та/або тимчасово діючі дво- або багатосторонні органи міжсекторального партнерства. Наприклад, Стратегією до 2020 року планувалося створити міжвідомчу комісію "Довкілля для України" за аналогією з процесом ЄЕК ООН "Довкілля для Європи", яка б упроваджувала механізми такого партнерства, зокрема щорічною підготовкою і проведенням національних конференцій, референдумів з екологічних питань за участі зацікавлених сторін, у тому числі й міжнародних партнерів.

Регулятивну підсистему може складати сукупність правових норм і норм звичаїв, моралі тощо, що регулюють відносини між соціальними партнерами, визначають порядки розроблення, прийняття та впровадження спільних екологічних рішень. Особливого значення набувають у цьому правові засади оцінювання впливу на довкілля планованої діяльності, стратегічної екологічної оцінки, екологічних рефререндумів тощо, у проведенні яких зацікавлені всі суб'єкти міжсекторального партнерства.

Функціональна підсистема може бути виражена у процесі взаємодії суб'єктів екологічного партнерства всіх рівнів шляхом проведення різноманітних консультацій, переговорів. Особливо вагомими тут можуть бути заходи економічного партнерства шляхом укладання договорів і угод, зокрема договорів державно-приватного партнерства, проведення тендерів на екологічне замовлення виконання програмних природоохоронних заходів, інвестиційних проєктів, спрямованих на подолання багатьох екологічних проблем, передусім кліматичних змін, у тому числі за рахунок бюджетних природоохоронних фондів.

У країні оптимально доцільно використовувати географрічне положення України, наявність у межах ії території прекрасних природних лікувальних, курортних, рекреаційних ресурсів, її кліматичних умов, що дозволить ефективно розвиватися всім видам туризму та наповнювати ії̈ бюджет додатковими коштами для забезпечення виконання природоохоронних заходів.

Комунікативна підсистема може включати систему соціально-партнерських відносин, серед яких будуть реалізовані спільні міжгалузеві проєкти нормативно-правового забезпечення реалізації державної екологічної політики, формуватиметься громадська екологічна думка, забезпечуватиметься проведення місцевих і національних екологічних ресререндумів, здійснюватимуться прямі комунікації між інститутами влади та громадськістю тощо.

Отже, екологічне міжсекторальне партнерство можна розглядати як законодавчо визначену взаємодію сторін із двох або більше секторів суспільного життя (держава, бізнес, наука, громадськість) під час розв'язання суспільно значимих екологічних проблем, що спрямована на досягнення цілей і завдань сучасної державної екологічної політики, яка покликана забезпечити паритет екологічних, економічних, соціальних інтересів усіх сторін у процесі побудови екологічно спрямованої, правової, демократичної країни України. 3 метою належної реалізації такого партнерства доцільно вдосконалювати чинне законодавство шляхом внесення відповідних змін і доповнень із цих питань.

\section{ВИСНОВКИ}

Проведене дослідження основ формування сучасної екологічної держави України підтверджує значимість, по-перше, відновлення духовного начала у взаєминах суспільства і Природи шляхом виконання її законів усіма його представниками на засадах генетичної пам'яті українців про нерозривні зв'язки з нею. По-друге, заходи із цих питань мають проводитися державою за участі всіх зацікавлених сторін за допомогою багатьох важелів, зокрема таких: екологічне партнерство, що здатне врівноважити баланс інтересів у цій сфері. По-третє, доцільним $є$ внесення змін у чинне законодавство, особливо шляхом визнання Природи найвищим соціальним благом. Такі засоби мають сформувати екологічно вмотивоване, демократичне, відповідальне перед собою та майбутніми поколіннями, а отже щасливе, громадянське суспільство.

\section{Список використаних джерел}

1. Оприлюднили рейтинг найщасливіших країн світу. URL: https://www.slovoidilo.ua/2021/03/19/novyna/svit/oprylyudnyly-rejtynhnajshhaslyvishyx-krayin-svitu (дата звернення: 15.07.2021).

2. У Нідерландах найвища в $€ С$ частка витрат на охорону довкілля - Євростат. URL: https://www.eurointegration.com.ua/news/2020/02/27/ 7106870/ (дата звернення: 15.07.2021).

3. Савісько М. Скільки та на що закладено у бюджеті 2020 для покращення екологічної ситуації в Україні? URL: https://voxukraine.org/ skilki-ta-na-shho-zakladeno-u-byudzheti-2020-dlya-pokrashhennyaekologichnoyi-situatsiyi-v-ukrayini/ (дата звернення: 15.07.2021).

4. Громадянське суспільство як чинник модернізації сучасної держави: матеріали Міжнародної науково-практичної конференції (м. Київ, 20 квітня 2021 р.). Київ: Київський регіональний центр НАПрН України, 2021. 248 c

5. Актуальні питання стратегії державної екологічної політики України на період до 2030 року: матеріали "круглого столу" (Харків, 21 трав. 2021 р.) / за заг. ред. А.П. Гетьмана та М.В. Шульги; М-во освіти і науки; Нац. акад. прав. наук України; Нац. юрид. ун-т ім. Ярослава Мудрого, каф. екол. права, каф. земел. та аграрн. права. Харків: Право, 2021. 384 с.

6. Еколого-правововий статус людини і громадянина : ретроспективний та перспективний погляди: збірн. матер. Міжнародної науковопрактичної конференції (м. Київ, 31 травня 2019 року) / Київський національний університет імені Тараса Шевченка, Інститут держави і права ім. В.М. Корецького НАН України: за заг. ред. Краснової М.В., Коваленко Т.О. Чернівці: Кондратьєв А.В. 2019. 392 с.

7. Про затвердження Основних засад (стратегії) державної екологічної політики України на період до 2020 року: Закон України від 28 лютого 2019 року № 2697-VIII. Відомості Верховної Ради України. 2019. № 16. Ст 70 .

8. Поняття правосвідомості. URL: https://uk.wikipedia.org/wiki/ \%D0\%9F\%D1\%80\%D0\%B0\%D0\%B2\%D0\%BE\%D1\%81\%D0\%B2\%D1\%96 \%D0\%B4\%D0\%BE\%D0\%BC\%D1\%96\%D1\%81\%D1\%82\%D1\%8C (дата звернення: 15.07.2021)

9. Лук'янець В. Парадигма. Філософський енциклопедичний словник / В.І. Шинкарук (гол. редкол.) та ін. Київ: Інститут філософії імені Григорія Сковороди НАН України: Абрис, 2002. 742 с.

10. Федоров В.Д. Актуальное и неактуальное в гидробиологии. Биологические науки. 1987. № 8. С. 6-25.

11. Екологічна демократія. URL: https://uk.wikipedia.org/wiki/\%D0\% 95\%D0\%BA\%D0\%BE\%D0\%BB\%D0\%BE\%D0\%B3\%D1\%96\%D1\%87\%D0\% BD\%D0\%B0 \%D0\%B4\%D0\%B5\%D0\%BC\%D0\%BE\%D0\%BA\%D1\%80\%D 0\%B0\%D1\%82\%D1\%96\%D1\%8F (дата звернення: 15.07 .2021 )

12. Права природи. URL: https://uk.wikipedia.org/wiki/\%D0\%9F\% D1\%80\%D0\%B0\%D0\%B2\%D0\%B0 \%D0\%BF\%D1\%80\%D0\%B8\%D1\%80 \%D0\%BE\%D0\%B4\%D0\%B8 (дата звернення: 15.07.2021)

13. Конституція Еквадору 2008 р. URL: https://ru.qaz.wiki/wiki/2008 Constitution of Ecuador (дата звернення: 15.07.2021).

14. Конституція Швейцарії. URL: http://www.ditext.com/swiss/ constitution.html (дата звернення: 15.07.2021)

15. Мещан І.В. Міжсекторне соціальне партнерство в системі соціального обслуговування: структурно-функціональні особливості. Нова парадигма: журнал наукових праць: Соціологія. Національний педагогічний університет імені М.П. Драгоманова, випуск 128 (2015). С. 178-188. 
16. Мельничук Л.М. Міжсекторальне партнерство у вітчизняній практиці державного управління соціальним розвитком регіонів. Державне управління: удосконалення та розвиток. 2017. № 5 http://www.dy.nayka.com.ua/?op=1\&z=1080 (дата звернення: 15.07.2021).

17. Міжсекторальні взаємодії як основа публічного управління: навч. посіб. / авт. кол.: С.О. Телешун, С.В. Ситник, І.В. Рейтерович та ін.; за заг. ред. С.О. Телешуна, д-ра політ. наук, проф. Київ: НАДУ, 2018. 224 c.

18. Галлямов Р.Р. Отечественные и зарубежные определения понятия "межсекторное социальное партнерство": сравнительный анализ основных подходов / Р.Р. Галлямов, Г.Д. Горбунова. Вестник ВЭГУ 2013. № 1(63). С. 26-32.

19. Діденко Н.Г. Державне управління і соціальне партнерство: актуальні проблеми теорії і практики: монографія. Донецьк: Східний видавничий дім, 2007. 404 с.

20. Неліпа Д.В. Особливості інституціоналізації соціального партнерства (політологічний аналіз): автореф. дис. на здобуття наук. ступеня канд. політ. наук: спец. 23.00.02 "Політичні інститути та процеси". К. 2005. 23 c.

\section{References}

1. Oprylyudnyly reytynh nayshchaslyvishykh krayin svitu. URL: https://www.slovoidilo.ua/2021/03/19/novyna/svit/oprylyudnyly-rejtynhnajshhaslyvishyx-krayin-svitu (data zvernennya: 15.07.2021). [The rating of the happiest countries in the world has been published. URL: https://www.slovoidilo.ua/2021/03/19/novyna/svit/oprylyudnyly-rejtynhnajshhaslyvishyx-krayin-svitu (date of application 15.07.2021)]

2. U Niderlandakh nayvyshcha v YES chastka vytrat na okhoronu dovkillya - Yevrostat. URL: https://www.eurointegration.com.ua/news/2020/02/ 27/7106870/ (data zvernennya: 15.07.2021). [The Netherlands Had the Highest Share of Environmental Spending in the EU - Eurostat. URL: https://www.eurointegration.com.ua/news/2020/02/27/7106870/ (date of application 15.07.2021)

3. Savis'ko M. Skil'ky ta na shcho zakladeno u byudzheti 2020 dlya pokrashchennya ekolohichnoyi sytuatsiyi v Ukrayini? URL: https://voxukraine.org/ skilki-ta-na-shho-zakladeno-u-byudzheti-2020-dlya-pokrashhennyaekologichnoyi-situatsiyi-v-ukrayini/ (data zvernennya: 15.07.2021). [Savisko M. How Much and for What is Included in the 2020 Budget to Improve the Environmental Situation in Ukraine? URL: https://voxukraine.org/skilkita-na-shho-zakladeno-u-byudzheti-2020-dlya-pokrashhennya-ekologichnoyisituatsiyi-v-ukrayini/ (date of application 15.07.2021)].

4. Hromadyans'ke suspil'stvo yak chynnyk modernizatsiyi suchasnoyi derzhavy: materialy Mizhnarodnoyi naukovo-praktychnoyi konferentsiyi (m. Kyyiv, 20 kvitnya 2021 r.). Kyyiv: Kyyivs'kyy rehional'nyy tsentr NAPrN Ukrayiny, 2021. $248 \mathrm{~s}$. [Civil Society as a Factor in the Modernization of the Modern State: materials of the International scientific-practical conference (Kyiv, April 20, 2021). Kyiv: Kyiv Regional Center of the National Academy of Pedagogical Sciences of Ukraine, 2021. 248 pages].

5. Aktual'ni pytannya stratehiyi derzhavnoyi ekolohichnoyi polityky Ukrayiny na period do 2030 roku: materialy "kruhloho stolu" (Kharkiv, 21 trav. 2021 r.) / za zah. red. A.P. Het'mana ta M.V. Shul'hy; M-vo osvity i nauky; Nats. akad. prav. nauk Ukrayiny; Nats. yuryd. un-t im. Yaroslava Mudroho, kaf ekol prava, kaf. zemel ta ahrar prava. Kharkiv: Pravo, 2021. 384 s. [Current Issues of The Strategy of State Environmental Policy of Ukraine for the Period Until 2030: materials of the "round table" (Kharkiv, May 21, 2021) / for general. ed. A. Hetman and M. Shulga; Ministry of Education and Science; Nat. acad. right. Sciences of Ukraine; Nat. law. Univ. named after Yaroslav the Wise, dept. env. law, dep. land. and agrarian. law Kharkiv: Pravo, 2021. 384 pages].

6 . Ekoloho-pravovovyy status lyudyny i hromadyanyna:retrospektyvnyy ta perspektyvnyy pohlyady: zbirn. mater. Mizhnarodnoyi naukovopraktychnoyi konferentsiyi (m. Kyyiv, 31 travnya 2019 roku) / Kyyivs'kyy natsional'nyy universytet imeni Tarasa Shevchenka, Instytut derzhavy i prava im. V.M. Korets'koho NAN Ukrayiny: za zah. red. Krasnovoyi M.V., Kovalenko T.O. Chernivtsi: Kondrat'yev A.V. 2019. 392 s. [Environmental and Legal Status of Man and Citizen: Retrospective and Perspective Views: collection. mater. International scientific-practical conference (Kyiv, May 31, 2019) / Taras Shevchenko National University of Kyiv, Institute of State and Law. V.M. Koretsky NAS of Ukraine: for the general. ed. Krasnova M.V., Kovalenko T.O., Chernivtsi: Kondratiev A.V. 2019. 392 pages]

7. Pro zatverdzhennya Osnovnykh zasad (stratehiyi) derzhavnoyi ekolohichnoyi polityky Ukrayiny na period do 2020 roku: Zakon Ukrayiny vid 28 Iyutoho 2019 roku № 2697-VIII. Vidomosti Verkhovnoyi Rady Ukrayiny. 2019. № 16. St.70. [Law of Ukraine On Approval of the Basic Principles (Strategy) of the State Environmental Policy of Ukraine for the period until 2020: Law of Ukraine of February 28, 2019 № 2697-VIII. Information of the Verkhovna Rada of Ukraine. 2019. № 16. Art.70].

8. Ponyattya pravosvidomosti. URL: https://uk.wikipedia.org/wiki/\%D0\% 9F\%D1\%80\%D0\%B0\%D0\%B2\%D0\%BE\%D1\%81\%D0\%B2\%D1\%96\%D0\% B4\%D0\%BE\%D0\%BC\%D1\%96\%D1\%81\%D1\%82\%D1\%8C (data zvernennya:
15.07.2021). [The concept of legal awareness. URL: https://en.wikipedia.org/ wiki/\%D0\%9F\%D1\%80\%D0\%B0\%D0\%B2\%D0\%BE\%D1\%81\%D0\%B2\%D $1 \% 96 \%$ D0\%B4 \% D0\% BE\% D0\% BC\% D1\% 96\% D1\% 81\% D1\% 82\% D1\% 8C (date of application 15.07.2021)]

9. Luk"yanets' V. Paradyhma. Filosofs'kyy entsyklopedychnyy slovnyk / V.I. Shynkaruk (hol. redkol.) ta in. Kyyiv: Instytut filosofiyi imeni Hryhoriya Skovorody NAN Ukrayiny: Abrys, 2002. 742 s. [Lukyanets V., Paradigm. Philosophical Encyclopedic Dictionary / V.I. Shinkaruk (editor in chief) and others. Kyiv: Hryhoriy Skovoroda Institute of Philosophy of the National Academy of Sciences of Ukraine: Abris, 2002. 742 pages]

10. Fedorov V.D. Aktual'noye i neaktual'noye $v$ gidrobiologii. Biologicheskiye nauki. 1987. № 8. S. 6-25. [Fedorov V.D. Relevant and Irrelevant in Hydrobiology. Biological sciences. 1987. № 8. pp. 6-25].

11. Ekolohichna demokratiya. URL: https://uk.wikipedia.org/wiki/\%D0\% 95\%D0\%BA\%D0\%BE\%D0\%BB\%D0\%BE\%D0\%B3\%D1\%96\%D1\%87\%D0 \%BD\%D0\%B0_\%D0\%B4\%D0\%B5\%D0\%BC\%D0\%BE\%D0\%BA\%D1\%80 \%D0\%B0\%D1\%82\%D1\%96\%D1\%8F (data zvernennya: 15.07.2021). [Environmental democracy. URL: https://en.wikipedia.org/wiki/\%D0\%95\% D0\%BA\%D0\%BE\%D0\%BB\%D0\%BE\%D0\%B3\%D1\%96\%D1\%87\%D0\%BD \%D0\%B0_\%D0\%B4\%D0\%B5\%D0\%BC\%D0\%BE\%D0\%BA\%D1\%80\%D0\% B0\%D1\%82\%D1\%96\%D1\%8F (date of application 15.07.2021)].

12. Prava pryrody. URL: https://uk.wikipedia.org/wiki/\%D0\%9F\% D1\%80\%D0\%B0\%D0\%B2\%D0\%B0 \%D0\%BF\%D1\%80\%D0\%B8\%D1\%80\% D0\%BE\%D0\%B4\%D0\%B8 (data zvernennya: 15.07.2021). [Rights of nature. URL: https://en.wikipedia.org/wiki/\%D0\%9F\%D1\%80\%D0\%B0\%D0\% B2\%D0\%B0 \%D0\%BF\%D1\%80\%D0\%B8\%D1\%80\%D0\%BE\%D0\%B4\%D 0\%B8 (date of application 15.07.2021)]

13. Konstytutsiya Ekvadoru 2008 r. URL: https://ru.qaz.wiki/wiki/2008 Constitution_of_Ecuador (data zvernennya: 15.07.2021). [Constitution of Ecuador 2008 URL: https://ru.qaz.wiki/wiki/2008_Constitution_of_Ecuador (date of application 15.07.2021)]

14. Konstytutsiya Shveytsariyi URL: http://www.ditext.com/swiss/ constitution.html (data zvernennya: 15.07.2021). [The Constitution of Switzerland. URL: http://www.ditext.com/swiss/constitution.html (date of application 15.07.2021)]

15. Meshchan I.V. Mizhsektorne sotsial'ne partnerstvo v systemi sotsial'noho obsluhovuvannya: strukturno-funktsional'ni osoblyvosti. Nova paradyhma: zhurnal naukovykh prats': Sotsiolohiya. Natsional'nyy pedahohichnyy universytet imeni M.P. Drahomanova, vypusk 128 (2015). S. 178-188. [Meschan I.V. Intersectoral Social Partnership in the System of Social Services: Structural and Functional Features. New paradigm: journal of scientific works: Sociology. National Pedagogical University named after MP Dragomanova, issue 128 (2015). Pp. 178-188.

16. Mel'nychuk L.M. Mizhsektoral'ne partnerstvo u vitchyznyaniy praktytsi derzhavnoho upravlinnya sotsial'nym rozvytkom rehioniv. Derzhavne upravlinnya: udoskonalennya ta rozvytok. 2017. № 5 . http://www.dy.nayka.com.ua/?op=1\&z=1080 (data zvernennya: 15.07.2021) [Melnichuk L.M., Intersectoral Partnership in the Domestic Practice of Public Administration of Social Development of Regions. Public administration: Improvement and Development. 2017. № 5 (date of application 15.07.2021)].

17. Mizhsektoral'ni vzayemodiyi yak osnova publichnoho upravlinnya: navch. posib. / avt. kol.: S.O. Teleshun, S.V. Sytnyk, I.V. Reyterovych ta in.; za zah red. S.O. Teleshuna, d-ra polit. nauk, prof. Kyyiv: NADU, 2018. 224 s. [Cross-sectoral Interactions as a Basis for Public Administration: textbook. way / authors: S.O. Teleshun, S.V. Sitnik, I.V. Reiterovich and others; under general ed. S.O. Teleshuna, Dr. Flight. Sciences, Prof. Kyiv: NAPA, 2018. 224 pages].

18. Gallyamov R.R. Otechestvennyye i zarubezhnyye opredeleniya ponyatiya "mezhsektornoye sotsial'noye partnerstvo": sravnitel'nyy analiz osnovnykh podkhodov / R.R. Gallyamov, G.D. Gorbunova. Vestnik VEGU. 2013. № 1(63). S. 26-32. [Gallyamov R.R., Domestic and Foreign Definitions of the Concept of "Intersectoral Social Partnership": a Comparative Analysis of Basic Approaches / R.R. Galliamov, G.D. Gorbunova. VEGU Bulletin. 2013. № 1 (63). Pp. 26-32]

19. Didenko N.H. Derzhavne upravlinnya i sotsial'ne partnerstvo: aktual'ni problemy teoriyi i praktyky: monohrafiya. Donets'k: Skhidnyy vydavnychyy dim, 2007. 404 s. [Didenko N.G., Public Administration and Social Partnership: Current Issues of Theory and Practice: a monograph. Donetsk: Eastern Publishing House, 2007. 404 pages].

20. Nelipa D.V. Osoblyvosti instytutsionalizatsiyi sotsial'noho partnerstva (politolohichnyy analiz): avtoref. dys. na zdobuttya nauk. stupenya kand. polit. nauk: spets. 23.00.02 "Politychni instytuty ta protsesy". K., 2005. 23 s. [Nelipa D.V., Peculiarities of Institutionalization of Social Partnership (Political Analysis): author's ref. dis. for science. degree of Cand. polit. science: special. 23.00.02 "Political institutions and processes". K., 2005. 23 pages].

Received: $20 / 06 / 2021$ 1st revision: $15 / 07 / 2021$ Accepted: $30 / 07 / 2021$

M. Krasnova, Dr. Sc. (Law), Prof.

Taras Shevchenko National University of Kyiv, Kyiv, Ukraine

\section{FUNDAMENTALS OF FORMATION OF MODERN ENVIRONMENTAL STATE IN UKRAINE}

The paper addresses the social, economic, environmental and legal bases of the modern Environmental state formation and prospects of this state's construction in Ukraine on the grounds of realization of the state policy. Peculiarities of realization of separate principles of the state policy, capable of promoting the formation of the environmental state, are considered. Based on the analysis of the formation of such states in some countries, the paper studies the ways to improve the legal framework for the formation of an environmentally friendly society, environmental partnership, as the main way to build an environmental state, and to ensure parity of environmental, economic and social needs in the context of sustaina- 
ble development. Particular attention is paid to the formation of the ecological paradigm as the basis for environmental legal consciousness of the whole society. This will allow the revision of values in relation to nature and recognize nature at the level of the Constitution of Ukraine as the basic social value. Attention is also paid to the structure, forms, methods, and content of environmental partnership, which can influence various factors in the formation of environmental state. It is proved that the main form of environmental partnership in modern conditions is a public-private partnership and that the latter is able to ensure the implementation of the effective environmental projects in the areas of natural resources restoration, waste management, eco-tourism etc. According to the structure, the environmental partnership is proposed to be considered as a set of institutional, regulatory, functional and communicative subsystems, possible content of which is also revealed. On the basis of the conducted research, the independent scientific conclusions and judgments on the analysed subjects are suggested and the ways of perfection of the current legislation of Ukraine on the outlined questions are offered.

Keywords: ecological democracy, environmental paradigm, environmental legal awareness, environmental policy, the principle of environmental partnership, environmental legislation.

Bulletin of Taras Shevchenko National University of Kyiv. Legal Studies, 2021; 3 (118): 56-63

УДК 349.3:369

DOI: https:doi.org/10.17721/1728-2195/2021/3.118-10
ISSN 1728-2195

(C) Taras Shevchenko National University of Kyiv, Publishing center "Kyiv University", 2021

\section{ОКРЕМІ АСПЕКТИ РОЗВИТКУ ЗАКОНОДАВСТВА У СФЕРІ СОЦІАЛЬНОГО СТРАХУВАННЯ ЗА ЧАСІВ НЕЗАЛЕЖНОСТІ УКРАÏНИ}

Проаналізовано розвиток законодавства у сфері соціального страхування протягом 1991-2021 років незалежності України (окремі аспекти реформування соціального страхування та розвитку законодавства у частині визначення страхового стажу й обчислення страхового внеску, які необхідні для отримання соціального забезпечення різних видів). Наголошено на передумовах законодавчих змін та їхніх наслідках. Також надано критичну оцінку якості законодавства з огляду на велику кількість рішень Конституційного Суду України про визнання неконституційним ряду положень законодавства, що свідчить про недостатню увагу законодавця до непорушення конституційних гарантій соціального захисту осіб. Звернено увагу на новації у правовому регулюванні, викликані військовими діями на Сході України та гострою респіраторною хворобою COVID-19, спричиненою коронавірусом SARS-CoV-2. Pозглянуто деякі законодавчі зміни, що мали значний суспільний інтерес та стосувалися значної кількості осіб. При визнанні Конституиійним Судом України неконституційними положень нормативно-правових актів не завжди слідує нормативне закріплення продовження врегулювання правовідносин зі спірного питання, що приводить до вакууму у правовому регулюванні. Наявність неузгоджень у нормативно-правових актах свідчить про потребу в аналізі чинного законодавства та покращенні якості нормативно-правових актів. Звернено увагу на те, що потребує врегулювання на законодавчому рівні питання зарахування до страхового стажу періоду, коли мобілізований працівник перебував у АТО у 20142016 роках, у зв'язку із чим запропоновано внести відповідні зміни до ст. 11 та 40 Закону України "Про загальнообов'язкове державне пенсійне страхування".

Ключові слова: соціальне страхування, пенсійна реформа, страховий стаж, єдиний соціальний внесок, компенсація заробітної плати.

\section{ВСТУП}

1991 року Україна здобула незалежність і протягом 30 років здійснює розбудову держави, зокрема і шляхом формування нормативно-правової бази, складником якої $€$ соціально-забезпечувальне законодавство. Розвиток суспільства, нові виклики спонукали до реформування як "отриманого у спадок" радянського законодавства, так і нормативно-правових актів, прийнятих за часів незалежності України. Нині Україна перебуває на шляху до створення якісної нормативно-правової бази. Протягом 30 років зроблено чимало, проте законодавство потребує постійного оновлення. На жаль, не завжди вдається законодавцю своєчасно та якісно реагувати на потребу у зміні законодавства.

Складником соціально-забезпечувальних правовідносин є правовідносини у сфері соціального страхування, які за роки незалежності України перебувають у процесі реформування, що викликано як потребою в ефективному використанні коштів, зокрема і на адміністрування процесів, так і демографічною ситуацією, економічними показниками та необхідністю унеможливити зловживання правом учасниками правовідносин. Указані фрактори серед інших впливають на розвиток законодавства в означеній сфері.

Аналіз останніх досліджень і публікацій. Історичний розвиток законодавства у сфрері соціального забезпечення та соціального страхування України зокрема, і за часів незалежності, і протягом усього часу існування законодавства на землях України, досліджували провідні українські вчені.
О. В. Москаленко у праці "Основні засади соціального страхування в сучасних умовах" зазначає, що "питання розвитку соціального страхування зводиться до пошуку шляхів досягнення балансу між економічною i соціальною складовими розвитку суспільства, які дозволили б уникнути конфронтації між ними та попередити перетворення соціального захисту населення 3 механізму управління соціальними ризиками на "баласт", який $€$ перепоною економічного зростання" [1, с. 126]. О. В. Тищенко у доробку "Тенденції розвитку законодавства про пенсійний вік" приділила увагу процесу реформування пенсійного забезпечення України у частині підвищення пенсійного віку [2]. М. І. Боднарук у монографії "Правове регулювання соціального страхування в Україні" запропонував таку періодизацію становлення та розвитку соціального страхування на території України: 1-й період (близько III тис. років до н. е. IX ст. н. е.); 2-й період (X-XVI ст.); 3-й період (XVIIXX ст.); 4 період (1991 р. - понині - специфічний розвиток соціального страхування в Україні за доби її незалежності, що характеризується прийняттям значної кількості базових нормативно-правових актів у сфері соціального страхування, реформаційними процедурами тощо) [3, с. 415]. У монографії "Проблеми теорії та нормативно-правового регулювання соціального страхування в Україні" авторка цієї статті звертає увагу на важливість розвитку соціального страхування, оскільки "виважена політика держави у сфері соціального страхування вигідна як державі, яка може залучати в економіку кошти страхових фондів для розвитку галузей, так і для застрахованих осіб, які протягом життя мають 